\title{
Clinical Outcomes of Positive Newborns for COVID-19 in Rio de Janeiro, Brazil
}

\author{
Karina Martins-Cardoso, ${ }^{1,2}$, Luana Ferreira Martins de Toledo ${ }^{3}$, Juliana Aparecida Souza Paz ${ }^{1}$, \\ Andressa Rangel de Oliveira Lima ${ }^{3}$, Thaís Chrispim de Souza Giangiarulo ${ }^{1,3}$, \\ Jéssica da Silva Oliveira1, IPB COVID Workgroup' ${ }^{1}$, Carla Carolina Teixeira3, \\ Jones Zitenfeld Cardia Neto4, Giovanna Geórgia Pires Carrilho Vallim³, \\ Shana Priscila Coutinho Barroso ${ }^{1}$
}

\begin{abstract}
${ }^{1}$ Laboratório de Biologia Molecular, Instituto de Pesquisas Biomédicas, Hospital Naval Marcílio Dias, Rio de Janeiro, Brasil ${ }^{2}$ Instituto de Bioquímica Médica Leopoldo de Meis, Universidade Federal do Rio de Janeiro, Rio de Janeiro, Brasil ${ }^{3}$ UTI neonatal, Clínica de Pediatria, Hospital Naval Marcílio Dias, Rio de Janeiro, Brasil ${ }^{4}$ Serviço de Patologia, Hospital Naval Marcílio Dias, Rio de Janeiro, Brasil

Email: jupazz@gmail.com
\end{abstract}

How to cite this paper: Martins-Cardoso, K., de Toledo, L.F.M., Paz, J.A.S., de Oliveira Lima, A.R., de Souza Giangiarulo, T.C., da Silva Oliveira, J., IPB COVID Workgroup, Teixeira, C.C., Neto, J.Z.C., Vallim, G.G.P.C. and Barroso, S.P.C. (2021) Clinical Outcomes of Positive Newborns for COVID-19 in Rio de Janeiro, Brazil. Open Journal of Obstetrics and Gynecology, 11, 1851-1861. https://doi.org/10.4236/ojog.2021.1112172

Received: October 25, 2021

Accepted: December 27, 2021

Published: December 30, 2021

Copyright (C) 2021 by author(s) and Scientific Research Publishing Inc. This work is licensed under the Creative Commons Attribution International License (CC BY 4.0).

http://creativecommons.org/licenses/by/4.0/ (c) (i) Open Access

\begin{abstract}
The disease caused by the SARS-CoV-2 virus has spread very rapidly throughout the world, causing various clinical manifestations and affecting several organs and systems. However, the possibility of vertical transmission of COVID19 in symptomatic pregnant women has been questioned. The aim of this work was to report cases of possible vertical transmission in pregnant women affected by the SARS-CoV-2 virus, as well as its clinical repercussions on the newborn. In this paper, we conducted a cross-sectional retrospective study by analyzing medical records of pregnant women admitted at the military hospital, Rio de Janeiro, Brazil, diagnosed with COVID-19 and who had positive newborns. To evaluate epidemiological data, clinical manifestations, and laboratory and histopathological changes were related to this vertical transmission. Only six newborns tested were positive for COVID-19. The mothers had no respiratory symptoms, and the gestational age was at term, except for one newborn born prematurely due to detection of pleural effusion. Three neonates had respiratory symptoms, requiring ventilatory support. None of the mothers or newborns died. During the pandemic, possible vertical transmission cases of infected pregnant women in the third trimester of pregnancy were observed. According to the case reports published in the literature, they illustrate phenotypes of neonatal involvement with varied clinical manifestations and severity; however, further scientific studies are needed to prove the effective vertical transmission of SARS-COV-2 in positive pregnant women.
\end{abstract}




\section{Keywords}

SARS-CoV-2 Infection, Neonatal Outcomes, Vertical Transmission

\section{Introduction}

Since February 2020, Brazil has been affected by a pandemic caused by the SARS-COV-2 virus, a predominantly respiratory transmission virus of the coronavirus family [1]. However, since then, other forms of transmission have been questioned, and there have been studies evidencing vertical transmission of this virus as well as the possibility of disease in the neonate [2] [3] [4].

The possibility of vertical transmission by COVID-19 has been a significant concern in symptomatic pregnant women [5] [6] [7] [8]. Previous studies pointed to those coronaviruses can affect severe adverse pregnancy outcomes [9]. However, some studies show that there appears to be minimal or no risk of vertical transmission to infants in maternal patients who tested are positive for COVID19 during the third trimester of pregnancy [10]-[15].

In contrast, there are studies reporting prematurity in newborns as a significant adverse factor in addition to cases of symptomatic newborns in mothers positive for this virus [16] [17] [18]. Recently, an adverse case of SARS-CoV-2 infection associated with inflammatory response and pericardial effusion, resulting in a premature delivery was observed [19].

Some evidences demonstrate the ability of Sars-CoV-2 infection in newborns through vertical transmission [20] [21]. Then, the objective of this study was to seek possible cases of neonates born infected with SARS-CoV-2 immediately after delivery.

This work is a retrospective review of medical records of all newborns who tested were positive for COVID-19 by performing a nasopharyngeal swab for Sars-CoV-2. Immediately after birth, signs, symptoms and the existence of adverse factors that may be related to this disease were assessed.

\section{Methods}

The research project was approved by the Institutional Review Board of Hospital Naval Marcílio Dias (HNMD), number 32382820.3.0000.5256.

This study was a retrospective review of medical records of pregnant women who tested positive for COVID-19 and were admitted for delivery at military hospital, located in Rio de Janeiro city, Brazil, from May 26, 2020 to February 28, 2021. The study design was based on previous research [10].

All pregnant women underwent a serological rapid test (Lepu Technology, China) to detect antibodies against SARS-CoV-2 at the time of admission. COVID-19 positive mothers had their newborns were screened with RT-PCR test, from a nasopharyngeal swab collected immediately post-delivery.

Clinical data, histopathological analysis of placental biopsies and laboratory 
tests of COVID-19 positive neonates and their mothers were assessed.

The evaluation consists of removing genetic material (RNA) from nasopharyngeal swabs and amniotic fluid. There was also extraction of genetic material from the pericardial fluid in one of the reported cases. The Maxwell ${ }^{\circledR}$ RSC instrument and Maxwell ${ }^{\circledast} 16$ Viral Total Nucleic Acid Purification Kit were used, according to the manufacturer's instructions (Promega). Viral RNA amplification assay was performed using GoTaq Probe kit (Promega/IDT). The presence of SARS-CoV-2 and human endogenous RNase P genes was detected by RTPCR using the CDC protocol.

\section{Results}

All pregnant admitted in the hospital are tested with rapid SARS-CoV-2 antigen and antibody before hospital admission. Among 922 parturient women, 57 were detected as positive for IgM and/or rapid antigen test, suggesting an active coronavirus infection at the time of admission, and all were in the third trimester of pregnancy. However, none of the pregnant women were symptomatic. Fifty-seven newborns have undergone a nasopharyngeal swab for SARS-COV-2; among these, 6 (10.5\%) were positive for COVID-19 (Table 1).

Most pregnant had previous comorbidities or acquired some gestational risk factor during pregnancy, except for the pregnant " 4 ". Four to six pregnant had previous comorbidities such as arterial hypertension, diabetes, or hypothyroidism. Pregnant " 2 " had a history of syphilis with inadequate treatment, and the neonate was VLDR reagent for syphilis. Due to these risk factors, all newborns were born by urgent cesarean (Table 1 ).

All pregnant women were in the third trimester of gestation. The range of gestational age of the newborns was 38 to 40 weeks, except for only one case. The gestational age was 33 weeks (case 4), considered premature with many complications post-birth.

Three newborns had symptoms soon after birth, two cases being respiratory symptoms and one cardiovascular case symptom. They needed ventilatory support, requiring hospitalization in the neonatal ICU for monitoring, in addition to clinical and hemodynamic management, and they had a good clinical evolution and were discharged from the hospital.

No women presented any postpartum complications, except for case 4, hospitalized four days after delivery due to endometritis and treated with intravenous antibiotics.

Laboratory tests analysis of four neonates up to 24 hours after birth were realized (Supplementary Table). There is a range of acceptable parameters for newborns, especially in the first 24 hours of life, which was not truly relevant in this clinical case. In case 3, where the neonate had sepsis, the number of leukocytes was altered. The D-dimer values measured in newborns in the first 24 hours of life were altered in three out of four neonates, which could show the presence of an inflammatory process. 
Table 1. Clinical parameters of mother and neonates with COVID-19.

\begin{tabular}{|c|c|c|c|c|c|c|}
\hline Maternal data & case 1 & case 2 & case 3 & case 4 & case 5 & case 6 \\
\hline Maternal age (year) & 32 & 22 & 25 & 27 & 26 & 30 \\
\hline $\begin{array}{c}\text { ABO system and } \\
\text { Rh factor }\end{array}$ & $A+$ & $\mathrm{O}+$ & $\mathrm{O}+$ & $\mathrm{O}+$ & $\mathrm{O}+$ & $\mathrm{O}+$ \\
\hline \multicolumn{7}{|l|}{$\begin{array}{l}\text { Serological for } \\
\text { SARS-CoV-2 }\end{array}$} \\
\hline $\operatorname{IgM}$ & Positive & Positive & Positive & Positive & NA & Positive \\
\hline IgG & Negative & Positive & Positive & Positive & NA & Negative \\
\hline $\begin{array}{l}\text { Comorbidity } \\
\text { record }\end{array}$ & $\begin{array}{c}\text { Arterial } \\
\text { hypertension }\end{array}$ & $\begin{array}{l}\text { Syphilis } \\
\text { (inadequate } \\
\text { treatment) }\end{array}$ & $\begin{array}{c}\text { Hypothyroidism, } \\
\text { DHEG, Asthma, } \\
\text { obesity }\end{array}$ & None & $\begin{array}{c}\text { Diabetes, } \\
\text { DHEG, Obesity }\end{array}$ & Hypothyroidism \\
\hline $\begin{array}{l}\text { Medication } \\
\text { management }\end{array}$ & None & None & $\begin{array}{l}\text { Puran T4, } \\
\text { Methyldopa }\end{array}$ & None & $\begin{array}{l}\text { Insulin, } \\
\text { Methyldopa }\end{array}$ & Puran T4 \\
\hline \multicolumn{7}{|l|}{ Neonate data } \\
\hline Gestational age & 38 weeks 2 days & 40 weeks 3 days & 39 weeks & 33 weeks 4 days & 38 weeks 2 days & 40 weeks 3 days \\
\hline $\begin{array}{l}\text { ABO system } \\
\text { and Rh factor }\end{array}$ & $\mathrm{A}+$ & $\mathrm{O}+$ & $\mathrm{A}+$ & $\mathrm{O}+$ & $\mathrm{A}+$ & $\mathrm{B}+$ \\
\hline Apgar & $8 / 9$ & $9 / 9$ & $8 / 9$ & $7 / 9$ & $7 / 8$ & $7 / 9$ \\
\hline Birth weight (g) & 3835 & 3550 & 3700 & 2400 & 3145 & 3595 \\
\hline \multicolumn{7}{|l|}{$\begin{array}{l}\text { Serological for } \\
\text { SARS-COV-2 }\end{array}$} \\
\hline $\operatorname{IgM}$ & Negative & Negative & Negative & Negative & NA & NA \\
\hline IgG & Negative & Positive & Negative & Positive & NA & NA \\
\hline Neonate symptoms & Asymptomatic & Asymptomatic & $\begin{array}{c}\text { Respiratory } \\
\text { distress, Sepsis }\end{array}$ & $\begin{array}{c}\text { Pericardial } \\
\text { effusion, } \\
\text { late-onset } \\
\text { neotanal sepsis }\end{array}$ & Asymptomatic & $\begin{array}{c}\text { Respiratory } \\
\text { distress }\end{array}$ \\
\hline Medication management & None & $\begin{array}{l}\text { Crystalline } \\
\text { penicillin }\end{array}$ & None & Antibiotics & None & None \\
\hline Respiratory support & None & None & $\mathrm{CPAP}^{1}$ & $\mathrm{VPP}^{2}, \mathrm{CPAP}$ & None & VPP \\
\hline Outcome & Discharge & Discharge & Discharge & Discharge & Discharge & Discharge \\
\hline
\end{tabular}

Note: ${ }^{1}$ Continuous positive airway pressure; ${ }^{2}$ Positive Pressure ventilation.

After delivery, four placentas of six pregnant women were histopathologically analyzed (Table 2). The analysis showed circulatory alterations in the maternal portion. Mild to moderate fibrin deposits were observed in the deciduous and subchorionic portion, in addition to the presence of thrombi and necrotic areas. Spots of hemorrhage and calcification in the intervillous spaces were also observed. 
Table 2. Placetal histopathological analysis of COVID-19 positive women.

\begin{tabular}{|c|c|c|c|c|c|c|}
\hline \multirow{2}{*}{$\begin{array}{l}\text { Method of } \\
\text { delivery }\end{array}$} & case 1 & case 2 & case 3 & case 4 & case 5 & case 6 \\
\hline & Cesarean & Cesarean & Cesarean & Cesarean & Cesarean & Cesarean \\
\hline $\begin{array}{l}\text { Placental } \\
\text { histopathology }\end{array}$ & $\begin{array}{l}\text { Circulatory changes } \\
\text { are moderate and } \\
\text { suggest maternal } \\
\text { vascular alteration. } \\
\text { In the intervillous } \\
\text { space, thrombi, } \\
\text { hemorrhage, } \\
\text { calcification and a } \\
\text { light/moderate } \\
\text { fibrin deposit are } \\
\text { observed. Deciduous } \\
\text { and subchorionic } \\
\text { region with mod- } \\
\text { erate fibrin deposit } \\
\text { and presence of } \\
\text { thrombi. }\end{array}$ & $\begin{array}{l}\text { Presence of } \\
\text { circulatory } \\
\text { changes: } \\
\text { retroplacental } \\
\text { thrombus and } \\
\text { fibrinoid } \\
\text { necrosis in the } \\
\text { wall of } \\
\text { deciduous } \\
\text { vessels. }\end{array}$ & $\begin{array}{l}\text { Presence of } \\
\text { an area } \\
\text { corresponding } \\
\text { to old infarction, } \\
\text { suggesting } \\
\text { maternal } \\
\text { vascular } \\
\text { alteration. } \\
\text { In the } \\
\text { intervillous } \\
\text { space, fibrin, } \\
\text { foci of } \\
\text { calcification } \\
\text { and hemorrhage } \\
\text { are noted, as } \\
\text { well as moderate } \\
\text { deposition of } \\
\text { fibrin of the } \\
\text { de decidua. }\end{array}$ & $\begin{array}{l}\text { Placenta of } \\
\text { increased size for } \\
\text { gestational age. } \\
\text { Vascular changes } \\
\text { are mild and } \\
\text { nonspecific. In the } \\
\text { intervillous space } \\
\text { there are foci of } \\
\text { calcification and } \\
\text { hemorrhage. The } \\
\text { deciduous has a } \\
\text { slight deposition of } \\
\text { fibrin and fibrinoid } \\
\text { necrosis in the wall } \\
\text { of some vessels. }\end{array}$ & NA & NA \\
\hline
\end{tabular}

\section{Discussion}

The risks of coronavirus infection in pregnancy, as well as in the newborn, remain limited. There are studies reporting prematurity as the major cause of coronavirus-related interference in pregnant women. However, it has been noted that there are reported cases of symptomatic and RT-PCR positive newborns for SARS-CoV-2 showing vertical transmission [22].

Three newborns (50\%) showed clinical symptoms, two with early respiratory distress and need for ventilatory support and one with a cardiovascular symptom with pericardial effusion [19]. Other clinical diagnoses were excluded through prenatal serologies panels.

This work sought to analyze the incidence of positive cases of pregnant women and newborns and possible vertical transmission. In agreement with the literature, cases of newborns with RT-PCR positive for SARS-Cov-2 are rare [20] [23] [24]. From May 2020 through March 2021, only six newborns were diagnosed with COVID-19.

According to Alzamora and collaborators (2020) [7], most pregnant women pass through infection with SARS-CoV-2 with no interferences at childbirth, an asymptomatic picture, or a mild picture. Few cases of pregnant women with severe acute respiratory syndrome caused by COVID-19 have been reported in the literature. Most cases of SARS-CoV-2 positive mothers had mild pictures of the disease or are asymptomatic [6] [25] [26].

In this study, besides one severe case where the fetus presented pleural effusion, requiring an emergency premature childbirth, the other pregnancies lasted 
until the third month, despite being in the acute phase of the infection at the time of childbirth. Evidence shows that pregnant women infected with SARSCoV-2 in the second trimester are at greater risk for complications such as miscarriage, fetal growth restriction, and preeclampsia [27]. It was also observed that the pregnant women reported in this cohort were respiratory asymptomatic. This corroborates with previously reported cases that symptomatic pregnant women for COVID-19 have a higher rate of preterm births than asymptomatic pregnant women [28].

All cases of newborns highlighted in this study were from cesarean childbirth. Possible routes of transmission through placenta, cord blood, amniotic fluid, and vaginal secretion generate concerns about neonate infection [29]. Because some papers discuss the recommendation of choosing cesarean childbirth as a protective measure against transmission of the infectious agent to the newborn. These recommendations are widely applied in cases of maternal Herpes, Hepatitis, and HIV infection [30]. However, there is no consistent evidence to guarantee that cesarean childbirth can prevent vertical transmission [31]. CAI and colleagues (2021) [29] found no relevance to choosing cesarean childbirth as a guarantee of preventing vertical transmission of the SARS-CoV-2 virus.

Infection caused by the new coronavirus can have several complications, and D-dimer's level can be a predictor of their severity, giving a poor prognosis with high values [32]. In addition, altered values can provide a picture of disseminated vascular coagulation in pregnant, which may lead to placental insufficiency with the presence of thrombi and placental vascular alterations, which can be seen in the histopathological examination of the analyzed placentas [33]. It is worth wondering if changes in D-dimer levels in pregnant women can predict some degree of placental insufficiency.

Pregnancy increases the state of hypercoagulability, increasing the risk of thromboembolic events [34]. Together with the massive amount of fibrin deposited in the placenta, inflammatory cell infiltration is associated with spontaneous abortion, fetal growth restriction, and preeclampsia [27]. The abnormality of maternal blood flow to the placenta leads to a possible drop in body oxygen saturation in the mother and may hurt the fetus, leading to premature childbirth or asphyxia of the newborn. As a result, severe damage to the newborn's organs and brain may occur [5] [35].

One-third of placental abnormalities reported in pregnant women affected by COVID-19 are related to maternal vascular insufficient perfusion. Another third, associated with the infiltration of immune system cells into the intervillous spaces [36]. Here, histopathological analyses of the placentas performed from four pregnant women showed vascular changes in the maternal portion in all cases, in addition to high fibrin deposition and presence of thrombi in the intervillous spaces and decidual vessels. One of the newborns (case 4) required positive pressure resuscitation and depended on CPAP as ventilatory support. However, further analysis would be required to ascertain any association between placental changes and SARS-Cov-2 infection. 
Although some works demonstrate the capacity of the new coronavirus to infect the placenta and cause damage, the newborn is not infected, reinforcing its effective barrier capacity for viral infection [37] [38]. Cases of vertical transmission are rare and require more investigations about the importance of the newborn clinical outcome.

The study concluded that coronavirus infection in pregnant women may have an effect on newborns. However, such placental or clinical changes do not appear to be associated with a high risk of neonatal survival, but rather with clinical complications after birth.

\section{Acknowledgements}

This work was supported by grants from The State of Rio de Janeiro Research Foundation-FAPERJ (E-26/010.000168/2020). We thank the Scientific Research Support Foundation of the Marcílio Dias Naval Hospital-Amarcilio, the Captain Dr. Marcelo Gregorio Leal, the Captain Antonio Vita de Moraes Júnior, rear admiral Oscar Artur de Oliveira Passos and the lieutenant Adriana Paula Macedo Ferreira Pereira for supporting this publication and execution of our work.

The Covid19-IPB Workgroup includes Raissa Mirella dos Santos Cunha da Costa, Sâmila Natiane Ferreira, Marlon Daniel Lima Tonin, Eduardo Siqueira, Rafaela da Silva Caetano, Vinicius Figueiredo Vizzoni.

\section{Declaration of Interest Statement}

The authors declare no conflicts of interests.

\section{References}

[1] Huang, C., Wang, Y., Li, X., Ren, L., Zhao, J., Hu, Y., et al. (2020) Clinical Features of Patients Infected with 2019 Novel Coronavirus in Wuhan, China. Lancet, 395, 497-596. https://doi.org/10.1016/S0140-6736(20)30183-5

[2] Zeng, L., Xia, S., Yuan, W., Yan, K., Xiao, F., Shao, J., et al. (2020) Neonatal Early-Onset Infection with SARS-CoV-2 in 33 Neonates Born to Mothers with Covid-19 in Wuhan, China. JAMA Pediatrics, 174, 722-725.

https://doi.org/10.1001/jamapediatrics.2020.0878

[3] Vivanti, A.J., Vauloup-Fellous, C., Prevot, S., Zupan, V., Suffee, C., Do Cao. J., Benachi, A., et al. (2020) Transplacental Transmission of SARS-CoV-2 Infection. Nature Communications, 11, Article No. 3572. https://doi.org/10.1038/s41467-020-17436-6

[4] Zeng, H., Chen, X., Fan, J., Tang, Y., Deng, Q., Zhang, W., et al. (2020) Antibodies in Infants Born to Mothers with Covid-19 Pneumonia. JAMA, 323, 1848-1849. https://doi.org/10.1001/jama.2020.4861

[5] Zhu, H., Wang, L., Fang, C., Peng, S., Zhang, L., Chang, G., et al. (2020) Clinical Analysis of 10 Neonates Born to Mothers with 2019-nCoV Pneumonia. Translational Pediatrics, 9, 51-60. https://doi.org/10.21037/tp.2020.02.06

[6] Yu, N., Li, W., Kang, Q., Xiong, Z., Wang, S., Lin, X., et al. (2020) Clinical Features and Obstetric and Neonatal Outcomes of Pregnant Patients with Covid-19 in Wuhan China: A Retrospective, Single-Center, Descriptive Study. The Lancet Infectious Diseases, 20, 559-564. https://doi.org/10.1016/S1473-3099(20)30176-6 
[7] Alzamora, M.C., Paredes, T., Caceres, D., Webb, C.M., Valdez, L.M. and La Rosa, M. (2020) Severe COVID-19 during Pregnancy and Possible Vertical Transmission. American Journal of Perinatology, 37, 861-865. https://doi.org/10.1055/s-0040-1710050

[8] Moreno, S.C., To, J., Chun, H. and Ngai, I.M. (2020) Vertical Transmission of COVID-19 to the Neonate. Infectious Diseases in Obstetrics and Gynecology, 2020, Article ID: 8460672. https://doi.org/10.1155/2020/8460672

[9] Alfaraj, S.H., Al-Tawfiq, J.A. and Memish, Z.A. (2019) Middle East Respiratory Syndrome Coronavirus (MERS-CoV) Infection during Pregnancy: Report of Two Cases \& Review of the Literature. Journal of Microbiology, Immunology and Infection, 52, 501-503. https://doi.org/10.1016/j.jmii.2018.04.005

[10] Chen, H., Guo, J., Wang, C., Luo, F., Yu, X., Zhang, W., et al. (2020) Clinical Characteristics and Intrauterine Vertical Transmission Potential of COVID-19 Infection in Nine Pregnant Women: A Retrospective Review of Medical Records. Lancet, 395, 809-815. https://doi.org/10.1016/S0140-6736(20)30360-3

[11] Chen, Y., Peng, H., Wang, L., Zhao, Y., Zeng, L., Gao, H., et al. (2020) Infants Born to Mothers with a New Coronavirus (COVID-19). Frontiers in Pediatrics, 8, Article No. 104. https://doi.org/10.3389/fped.2020.00104

[12] Liu, Y., Chen, H., Tang, K. and Guo, Y. (2020) Clinical Manifestations and Outcome of SARS-CoV-2 Infection during Pregnancy. Journal of Infection. https://doi.org/10.1016/j.jinf.2020.02.028

[13] Gatta, A.N.D., Rizzo, R., Pilu, G. and Simonazzi, G. (2020) Coronavirus Disease 2019 during Pregnancy: A Systematic Review of Reported Cases. American Journal of Obstetrics and Gynecology, 223, 36-41. https://doi.org/10.1016/j.ajog.2020.04.013

[14] Yan, J., Guo, J., Fan, C., Juan, J., Yu, X., Li, J., et al. (2020) Coronavirus Disease 2019 in Pregnant Women: A Report Based on 116 Cases. American Journal of Obstetrics and Gynecology, 223, 111.E1-111.E14. https://doi.org/10.1016/j.ajog.2020.04.014

[15] Antouna, L., Taweelb, N.E., Ahmedc, I., Patnic, S. and Honestd, H. (2020) Maternal COVID-19 Infection, Clinical Characteristics, Pregnancy, and Neonatal Outcome: A Prospective Cohort Study. European Journal of Obstetrics \& Gynecology and Reproductive Biology, 252, 559-562. https://doi.org/10.1016/j.ejogrb.2020.07.008

[16] Di Mascio, D., Khalil, A., Saccone, G., Rizzo, G., Buca, D., Liberati, M., et al. (2020) Outcome of Coronavirus Spectrum Infections (SARS, MERS, COVID-19) during Pregnancy: A Systematic Review and Meta-Analysis. American Journal of Obstetrics \& Gynecology, 2, Article ID: 100107. https://doi.org/10.1016/j.ajogmf.2020.100107

[17] Yildiz, H., Yarci, E., Bozdemir, S.E., Ozdinc Kizilay, N., Mengi, S., Beskardesler, N., et al. (2021) Covid-19 Associated Cerebral White Matter Injury in A Newborn Infant with Afebrile Seizure. The Pediatric Infectious Disease Journal, 40, e268-e269. https://doi.org/10.1097/INF.0000000000003143

[18] He, Z., Fang, Y., Zuo, Q., Huang, X., Huang, X., Lei, Y., Ren, X., et al. (2021) Vertical Transmission and Kidney Damage in Newborns Whose Mothers Had Coronavirus Disease 2019 during Pregnancy. International Journal of Antimicrobial Agents, 57, Article ID: 106260. https://doi.org/10.1016/j.ijantimicag.2020.106260

[19] Lima, A.R.O., Cardoso, C.C., Bentim, P.R.B., Voloch, C.M., Rossi, Á.D., da Costa, R.M.M.S.C., et al. (2021) Maternal SARS-CoV-2 Infection Associated to Systemic Inflammatory Response and Pericardial Effusion in the Newborn: A Case Report. Journal of the Pediatric Infectious Diseases Society, 10, 536-539. https://doi.org/10.1093/jpids/piaa133 
[20] Sun, M., Xu, G., Yang, Y., Tao, Y., Pian-Smith, M., Madhavan, V., et al. (2020) Evidence of Mother-To-Newborn Infection with COVID-19. British Journal of Anaesthesia, 125, e245-e247. https://doi.org/10.1016/j.bja.2020.04.066

[21] Carbayo-Jiménez, T., Carrasco-Colom, J., Epalza, C., Folgueira, D., Pérez-Rivilla, A., Barbero-Casado, P., et al. (2021) Severe Acute Respiratory Syndrome Coronavirus 2 Vertical Transmission from an Asymptomatic Mother. The Pediatric Infectious Disease Journal, 40, e115-e117. https://doi.org/10.1097/INF.0000000000003028

[22] Fenizia, C., Biasin, M., Cetin, I., Vergani, P., Mileto, D., Spinillo, A., et al. (2020) Analysis of SARS-CoV-2 Vertical Transmission during Pregnancy. Nature Communications, 11, Article No. 5128. https://doi.org/10.1038/s41467-020-18933-4

[23] Schwartz, D.A. and Dhaliwal, A. (2020) Infections in Pregnancy with Covid-19 and Other Respiratory RNA Virus Diseases Are Rarely, If Ever, Transmitted to the Fetus: Experiences with Coronaviruses, Parainfluenza, Metapneumovirus Respiratory Syncytial Virus, and Influenza. Archives of Pathology \& Laboratory Medicine, 144, 920-928. https://doi.org/10.5858/arpa.2020-0211-SA

[24] Goh, X.L., Low, Y.F., Ng, C.H., Amin, Z. and Ng, Y.P.M. (2021) Incidence of SARSCoV-2 Vertical Transmission: A Meta-Analysis. Archives of Disease in Childhood: Fetal and Neonatal Edition, 106, 112-113. https://doi.org/10.1136/archdischild-2020-319791

[25] Li, N., Han, L., Peng, M., Lv, Y., Ouyang, Y., Liu, K., et al. (2020) Maternal and Neonatal Outcomes of Pregnant Women with Coronavirus Disease 2019 (COVID19) Pneumonia: A Case-Control Study. Clinical Infectious Diseases, 71, 2035-2041. https://doi.org/10.1093/cid/ciaa352

[26] Maeda, M.F.Y., Brizot, M.L., Gibelli, M.A.B.C., Ibidi, S.M., Carvalho, W.B., Hoshida, M.S., et al. (2021) Vertical Transmission of SARS-CoV2 during Pregnancy: A High-Risk Cohort. Prenatal Diagnosis, 41, 998-1008. https://doi.org/10.1002/pd.5980

[27] Hosier, H., Farhadian, S., Morotti, R.A., Deshmukh, U., Lu-Culligan, A., Campbell, K.H., et al. (2020) SARS-CoV-2 Infection of the Placenta. Journal of Clinical Investigation, 130, 4947-4953. https://doi.org/10.1172/JCI139569

[28] London, V., McLaren, R., Atallah, F., Cepeda, C., McCalla, S., Fisher, N., et al. (2020) The Relationship between Status at Presentation and Outcomes among Pregnant Women with COVID-19. American Journal of Perinatology, 37, 991-994. https://doi.org/10.1055/s-0040-1712164

[29] Cai, J., Tang, M., Gao, Y., Zhang, H., Yang, Y., Zhang, D., et al. (2021) Cesarean Section or Vaginal Delivery to Prevent Possible Vertical Transmission from a Pregnant Mother Confirmed with COVID-19 to a Neonate: A Systematic Review. Frontiers in Medicine, 8, Article ID: 634949. https://doi.org/10.3389/fmed.2021.634949

[30] Yang, M., Qin, Q., Fang, Q., Jiang, L. and Nie, S. (2017) Cesarean Section to Prevent Mother-To-Child Transmission of Hepatitis B Virus in China: A Meta-Analysis. BMC Pregnancy Childbirth, 17, Article No. 303. https://doi.org/10.1186/s12884-017-1487-1

[31] World Health Organization (2018) WHO Recommendation : Elective C-Section Should Not Be Routinely Recommended to Women Living with HIV. World Health Organization, Geneva.

[32] Lippi, G. and Favaloro, E.J. (2020) D-Dimer Is Associated with Severity of Coronavirus Disease 2019: A Pooled Analysis. Thrombosis and Haemostasis, 120, 876-877. https://doi.org/10.1055/s-0040-1709650 
[33] Neiger, R., Krohn, H.J. and Trofatter, M.O. (1997) Plasma Fibrin D-Dimer in Pregnancies Complicated by Partial Placental Abruption. Tennessee Medicine, 90, $403-$ 405.

[34] Brenner, B. (2004) Haemostatic Changes in Pregnancy. Thrombosis Research, 114, 409-414. https://doi.org/10.1016/j.thromres.2004.08.004

[35] Schwartz, D.A. and Graham, A.L. (2020) Potential Maternal and Infant Outcomes from Coronavirus 2019-NCOV (SARS-CoV-2) Infecting Pregnant Women: Lessons from SARS, MERS, and Other Human Coronavirus Infections. Viruses, 12, Article No. 194. https://doi.org/10.3390/v12020194

[36] Wong, Y.P., Khong, T.Y. and Tan, G.C. (2021) The Effects of COVID-19 on Placenta and Pregnancy: What Do We Know So Far? Diagnostics, 11, Article No. 94. https://doi.org/10.3390/diagnostics11010094

[37] Cribiù, F.M., Erra, R., Pugni, L., Rubio-Perez, C., Alonso, L., Simonetti, S., et al. (2021) Severe SARS-CoV-2 Placenta Infection Can Impact Neonatal Outcome in the Absence of Vertical Transmission. Journal of Clinical Investigation, 131, Article ID: e145427. https://doi.org/10.1172/JCI145427

[38] Colson, A., Depoix, C.L., Dessilly, G., Baldin, P., Danhaive, O., Hubinont, C., et al. (2021) Clinical and in Vitro Evidence against Placenta Infection at Term by Severe Acute Respiratory Syndrome Coronavirus 2. The American Journal of Pathology, 19, 1610-1623. https://doi.org/10.1016/j.ajpath.2021.05.009 


\section{Supplementary Table S1}

Table S1. Laboratory tests of positive COVID-19 neonates 24 hours after birth.

\begin{tabular}{|c|c|c|c|c|c|c|}
\hline Laboratory tests & case 1 & case 2 & case 3 & case 4 & case 5 & case 6 \\
\hline Coombs' test & Negative & Negative & Negative & Negative & Positive & Positive \\
\hline \multicolumn{7}{|l|}{ Neonate data } \\
\hline $\mathrm{Hb}(\mathrm{g} / \mathrm{dl})$ & 13.4 & 17.2 & 11.4 & 12.4 & NA & NA \\
\hline Ht (\%) & 36.8 & 52.2 & 32 & 34.8 & 46.8 & 49.5 \\
\hline Leukocytes (counts/mm³) & 8800 & 13,000 & 26,100 & 10,500 & NA & NA \\
\hline Lymphocytes (\%) & 39 & 23 & 18 & NA & NA & NA \\
\hline Neutrophils (\%) & 46 & 66.7 & 58 & NA & NA & NA \\
\hline Platelets (counts $/ \mathrm{mm}^{3}$ ) & 257,000 & 355,000 & 335,000 & 276,000 & NA & NA \\
\hline C-reactive protein $(\mathrm{mg} / \mathrm{dL})$ & 1.0 & 1.1 & 1.4 & 1.0 & NA & NA \\
\hline D-Dimer $(\mu \mathrm{g} / \mathrm{L})$ & 779 & 380 & 1460 & 2200 & NA & NA \\
\hline Aspartate aminotransferase (U/L) & 47 & 34 & 50 & 28 & NA & NA \\
\hline Alanine aminotransferase (U/L) & 21 & 13 & 7 & 6 & NA & NA \\
\hline Gamma-GT (U/L) & 148.8 & 46.2 & 90 & 750 & NA & NA \\
\hline Total bilirrubin (mg/dL) & 8.3 & 4.3 & 2.6 & 2.1 & 8.6 & 3.0 \\
\hline Direct bilirrubin (mg/dL) & 0.6 & 0.7 & 0.8 & 0.6 & 0.5 & 0.6 \\
\hline Indirect bilirrubin $(\mathrm{mg} / \mathrm{dL})$ & 7.7 & 3.6 & 1.6 & 1.5 & 8.1 & 2.4 \\
\hline Troponin $(\mu \mathrm{g} / \mathrm{mL})$ & $<0.010$ & 0.089 & 0.02 & 0.314 & NA & NA \\
\hline Creatine phosphokinase (U/L) & 314 & 284 & 728.5 & 695 & NA & NA \\
\hline Mass Creatine Kinase $(\mu \mathrm{g} / \mathrm{mL})$ & 14 & 15.5 & 12.2 & 41.6 & NA & NA \\
\hline
\end{tabular}

